\title{
Streptohalobacillus salinus gen. nov., sp. nov., a moderately halophilic, Gram-positive, facultative anaerobe isolated from subsurface saline soil
}

\author{
Xiaowei Wang, ${ }^{1,2}$ Yanfen $\mathrm{Xue}^{1}$ and Yanhe $\mathrm{Ma}^{1}$ \\ ${ }^{1}$ State Key Laboratory of Microbial Resources, Institute of Microbiology, Chinese Academy of \\ Sciences, Beijing 100101, PR China \\ ${ }^{2}$ Graduate University of the Chinese Academy of Sciences, Beijing 100049, PR China
}

Correspondence

Yanfen Xue

xueyf@im.ac.cn

\begin{abstract}
A Gram-stain-positive, rod-shaped, non-sporulating, motile and moderately halophilic bacterium, designated strain $\mathrm{H} 96 \mathrm{~B}^{\top} \mathrm{O}^{\top}$, was isolated from a saline soil sample of the Qaidam basin, China. The strain was facultatively anaerobic. Major end products formed from glucose fermentation were acetate, ethanol and lactic acid. The cell-wall peptidoglycan contained meso-diaminopimelic acid as the diagnostic diamino acid. The isoprenoid quinone component was menaquinone-6 (MK-6). The predominant cellular fatty acids were $C_{16: 0}$, anteiso- $C_{13: 0}$ and anteiso- $C_{15: 0}$. The genomic DNA G $+\mathrm{C}$ content of strain $\mathrm{H} 96 \mathrm{~B} 60^{\top}$ was $36.2 \mathrm{~mol} \%$. Phylogenetic analysis based on comparative 16S rRNA gene sequences indicated that strain $\mathrm{H} 96 \mathrm{~B} 6 \mathrm{O}^{\top}$ represented a novel phyletic lineage within the family Bacillaceae and was related most closely to Halolactibacillus species (96.1-96.4\% similarity). Based on the phenotypic, chemotaxonomic and phylogenetic data presented, strain $\mathrm{H} 96 \mathrm{~B} 60^{\top}$ is considered to represent a novel species of a new genus, for which the name Streptohalobacillus salinus gen. nov., sp. nov. is proposed. The type strain of Streptohalobacillus salinus is $\mathrm{H} 6 \mathrm{~B} 60^{\top}\left(=\mathrm{DSM} 22440^{\top}=\mathrm{CGMCC}^{\top} 1.7733^{\top}\right)$.
\end{abstract}

Isolation and polyphasic taxonomic studies have shown that Gram-positive, spore-forming, moderately halophilic or halotolerant, aerobic or facultatively anaerobic rods are highly heterogeneous and comprise a number of phylogenetically distinct lineages within rRNA 1 group of Ash et al. (1991) in the phyletic assemblage of bacteria classically defined as representing the genus Bacillus (Ash et al., 1991; Priest, 1981; Stackebrandt \& Liesack, 1993; Nielsen et al., 1994). They have been isolated mostly from saline or hypersaline environments such as salt lakes, salterns, seawater, saline soils, soda lakes and salted foods (Kushner, 1985; Ventosa et al., 1998), and some of the species have been subjected to polyphasic taxonomic study and reclassified within several new genera such as Halobacillus (Spring et al., 1996), Virgibacillus (Heyndrickx et al., 1998), Gracilibacillus (Wainø et al., 1999), Filobacillus (Schlesner et al., 2001), Oceanobacillus (Lu et al., 2001), Lentibacillus (Yoon et al., 2002), Paraliobacillus (Ishikawa et al., 2002), Halolactibacillus (Ishikawa et al., 2005), Tenuibacillus (Ren \& Zhou, 2005), Thalassobacillus (García et al., 2005), Sediminibacillus (Carrasco et al., 2008) and Natronobacillus (Sorokin et al., 2008).

The GenBank/EMBL/DDBJ accession number for the 16S rRNA gene sequence of strain $\mathrm{H} 96 \mathrm{~B} 60^{\top}$ is $\mathrm{FJ} 746578$.

A supplementary figure and two supplementary tables are available with the online version of this paper.
During the course of a study of microbial diversity of subsurface saline soil at a scientific drilling site $\left(37^{\circ} 03^{\prime} 50^{\prime \prime}\right.$ $\mathrm{N} 94^{\circ} 43^{\prime} 41^{\prime \prime} \mathrm{E}$ ) in the Qaidam basin of China, a great variety of moderately halophilic strains were isolated. Phylogenetic analysis based on 16S rRNA gene sequence comparisons indicated that most of the moderately halophilic isolates were related to the genera Bacillus, Salinicoccus, Marinobacter, Halomonas, Idiomarina, Halolactibacillus, Halobacillus, Thalassobacillus and Virgibacillus. Here, we describe the phenotypic and genotypic characteristics of one of these moderately halophilic strains, designated $\mathrm{H} 96 \mathrm{~B} 60^{\mathrm{T}}$, which appeared to represent a novel species of a new genus.

Strain $\mathrm{H} 96 \mathrm{~B} 60^{\mathrm{T}}$ was isolated by the standard dilutionplating technique on SG agar. The SG medium $(\mathrm{pH}$ adjusted to 8.0 with $1 \mathrm{M} \mathrm{NaOH}$ before autoclaving at $121{ }^{\circ} \mathrm{C}$ for $20 \mathrm{~min}$ ) contained the following (per litre): $7.5 \mathrm{~g}$ Casamino acids (Difco), $10.0 \mathrm{~g}$ yeast extract (Difco), $1.0 \mathrm{~g}$ sodium glutamate, $3.0 \mathrm{~g}$ trisodium citrate, $20.0 \mathrm{~g}$ $\mathrm{MgSO}_{4} .7 \mathrm{H}_{2} \mathrm{O}, 2.0 \mathrm{~g} \mathrm{KCl}, 80.0 \mathrm{~g} \mathrm{NaCl}$ and trace amounts of $\mathrm{FeSO}_{4} \cdot 7 \mathrm{H}_{2} \mathrm{O}$ and $\mathrm{MnCl}_{2} \cdot 4 \mathrm{H}_{2} \mathrm{O}$ (Sehgal \& Gibbons, 1960). Strain $\mathrm{H} 96 \mathrm{~B} 60^{\mathrm{T}}$ was cultured routinely on modified GM medium ( $\mathrm{pH}$ 7.5) containing the following (per litre): 5.0 g Casamino acids (Difco), 5.0 g yeast extract (Difco), $70.0 \mathrm{~g} \mathrm{NaCl}, 5.0 \mathrm{~g} \mathrm{MgSO}_{4} .7 \mathrm{H}_{2} \mathrm{O}, 2.0 \mathrm{~g} \mathrm{KCl}$ and trace amounts of $\mathrm{FeSO}_{4} \cdot 7 \mathrm{H}_{2} \mathrm{O}$ and $\mathrm{MnCl}_{2} \cdot 4 \mathrm{H}_{2} \mathrm{O}$ (Wang et al., 2009). Strain $\mathrm{H} 96 \mathrm{~B} 60^{\mathrm{T}}$ was maintained in this modified 
medium supplemented with $30 \%(\mathrm{v} / \mathrm{v})$ glycerol at $-80{ }^{\circ} \mathrm{C}$ for long-term preservation.

The phenotypic characteristics of the novel strain were determined by using methods described previously (Wang et al., 2009), including Gram-type (staining and nonstaining methods), morphology, growth properties, susceptibility to antimicrobial agents, catalase and oxidase activities, methyl red reaction, $\mathrm{H}_{2} \mathrm{~S}$ production, indole production, Voges-Proskauer reaction, urease production, nitrate reduction and API $50 \mathrm{CH}$ tests. For analysis of anaerobic fermentation, strain $\mathrm{H} 96 \mathrm{~B} 60^{\mathrm{T}}$ was cultivated in modified GYPF medium under a gaseous atmosphere of $100 \% \mathrm{~N}_{2}$ in anaerobic tubes. The GYPF medium ( $\mathrm{pH}$ adjusted to 8.0 with $1 \mathrm{M} \mathrm{NaOH}$ before autoclaving at $121{ }^{\circ} \mathrm{C}$ for $20 \mathrm{~min}$ ) contained the following (per litre): $10.0 \mathrm{~g}$ glucose, $5.0 \mathrm{~g}$ yeast extract (Difco), $5.0 \mathrm{~g}$ polypeptone, $1.0 \mathrm{~g} \mathrm{~K}_{2} \mathrm{HPO}_{4}, 70.0 \mathrm{~g} \mathrm{NaCl}, 5.0 \mathrm{~g} \mathrm{MgSO}_{4}$. $7 \mathrm{H}_{2} \mathrm{O}$ and $2.0 \mathrm{~g} \mathrm{KCl}$. Fermentation products from glucose were analysed by HPLC as described by Ishikawa et al. (2003). A Durham tube was placed in an anaerobic tube to detect gas production from glucose under anaerobic fermentation conditions. The production of extracellular hydrolases was detected on GM agar plates containing different enzyme substrates. The following enzyme activities were assayed as described previously: amylase and pullulanase (Ryan et al., 2006), proteolysis and lipolysis (Sánchez-Porro et al., 2003), $\beta$-glucosidase (Saqib \& Whitney, 2006; Kwon et al., 1994), DNase (Jeffries et al., 1957), phosphatase (Quesada et al., 1984) and gelatinase (Ventosa et al., 1982).

Preparation of the cell wall and determination of peptidoglycan structure were performed by using the methods described by Schleifer \& Kandler (1972) with the modification that TLC on cellulose sheets was used instead of paper chromatography. The amino acid composition of the cell-wall hydrolysate was determined by using one-dimensional descending film chromatography on cellulose sheets. Respiratory quinones were extracted according to the method of Collins et al. (1977) and were analysed by reversed-phase HPLC (Groth et al., 1996). Fatty acids were extracted, methylated and analysed by GC by using the standard Sherlock MIDI system (Microbial Identification) (Sasser, 1990; Kämpfer \& Kroppenstedt, 1996). Cell mass for the above procedures was obtained by cultivating strain $\mathrm{H} 96 \mathrm{~B} 60^{\mathrm{T}}$ at $37^{\circ} \mathrm{C}$ on GM agar. The genomic DNA G $+\mathrm{C}$ content of the strain was determined by the thermal denaturation method according to Marmur \& Doty (1962).

Genomic DNA of strain H96B60 ${ }^{\mathrm{T}}$ was extracted by using the method described by Marmur (1961). The 16S rRNA gene was amplified by PCR by using the universal primers described by Duckworth et al. (1996). The almost-complete nucleotide sequence was determined by direct sequencing and was compared with available $16 \mathrm{~S}$ rRNA gene sequences in the GenBank database by using the BLAST program. Multiple alignments with sequences of closely related members of the family Bacillaceae were performed by using the CLUSTAL x program (Thompson et al., 1997). Ambiguous and unalignable bases were omitted manually and the phylogenetic tree was then reconstructed from the evolutionary distance matrix calculated by using the neighbour-joining, minimum-evolutionary and maximum-parsimony methods in the MEGA program (version 3.1; Kumar et al., 2004). Robustness of the resultant tree topology was evaluated by bootstrap resampling analysis with 1000 replicates (Felsenstein, 1985).

The phenotypic characteristics of strain $\mathrm{H} 96 \mathrm{~B} 60^{\mathrm{T}}$ are presented in the genus and species descriptions. The cellwall peptidoglycan of strain $\mathrm{H} 96 \mathrm{~B} 60^{\mathrm{T}}$ contained mesodiaminopimelic acid as the diagnostic diamino acid. The menaquinone component detected in cells of strain H96B60 ${ }^{\mathrm{T}}$ was menaquinone-6 (MK-6). Cells contained large amounts of straight-chain and branched fatty acids. The major components ( $>15 \%$ of total fatty acids) were $\mathrm{C}_{16: 0}$, anteiso- $\mathrm{C}_{13: 0}$ and anteiso- $\mathrm{C}_{15: 0}$ (see Supplementary Table S1 in IJSEM Online). The genomic DNA G+C content of strain $\mathrm{H} 96 \mathrm{~B} 60^{\mathrm{T}}$ was $36.2 \mathrm{~mol} \%$. The $16 \mathrm{~S}$ rRNA gene sequence of strain $\mathrm{H} 96 \mathrm{~B} 60^{\mathrm{T}}$ determined in this study comprised $1481 \mathrm{nt}$. Comparative 16S rRNA gene sequence analyses revealed that strain $\mathrm{H} 96 \mathrm{~B} 60^{\mathrm{T}}$ was phylogenetically related most closely to members of the family Bacillaceae. In the phylogenetic tree based on the neighbour-joining algorithm, strain $\mathrm{H} 96 \mathrm{~B} 60^{\mathrm{T}}$ formed a lineage independent of those of members of the family Bacillaceae (Fig. 1); it was related most closely to the type strains of Halolactibacillus species (96.1-96.4\% $16 \mathrm{~S}$ rRNA gene sequence similarity). The topologies of phylogenetic trees constructed by using the minimum-evolutionary and maximum-parsimony algorithms were similar to that of the tree constructed with the neighbour-joining analysis (Supplementary Fig. S1). Strain H96B60 ${ }^{\mathrm{T}}$ shared less than $95.1 \% 16 \mathrm{~S}$ rRNA gene sequence similarity with other spore-forming, halophilic or halotolerant taxa in the family Bacillaceae, such as type strains of species of Amphibacillus (93.6-95.1\%), Paraliobacillus (95.1-95.3\%) and Gracilibacillus (94.2-94.4\%) and Natronobacillus azotifigens $24 \mathrm{KS}-1^{\mathrm{T}}$ (the sole species of the genus Natronobacillus; $95.0 \%)$.

Our phylogenetic analysis thus showed that strain $\mathrm{H} 96 \mathrm{~B} 60^{\mathrm{T}}$ represents a novel branch within the Gram-positive, sporeforming, moderately halophilic or halotolerant rod-shaped bacteria. Although strain $\mathrm{H} 96 \mathrm{~B} 60^{\mathrm{T}}$ exhibited closest phylogenetic affiliation to Halolactibacillus species, it could be clearly distinguished from members of the genus Halolactibacillus by differences in physiological and chemotaxonomic properties, in particular the requirement for glucose for growth under aerobic conditions, oxidase activity and respiratory quinone; strain $\mathrm{H} 96 \mathrm{~B} 60^{\mathrm{T}}$ did not require glucose for growth under aerobic conditions and may possess a respiratory chain, given that it was positive for respiratory quinone and oxidase, whereas Halolactibacillus halophilus requires glucose for growth under aerobic conditions and its cells lack cytochromes and quinone components. Thus, $H$. halophilus grows aerobically by using 


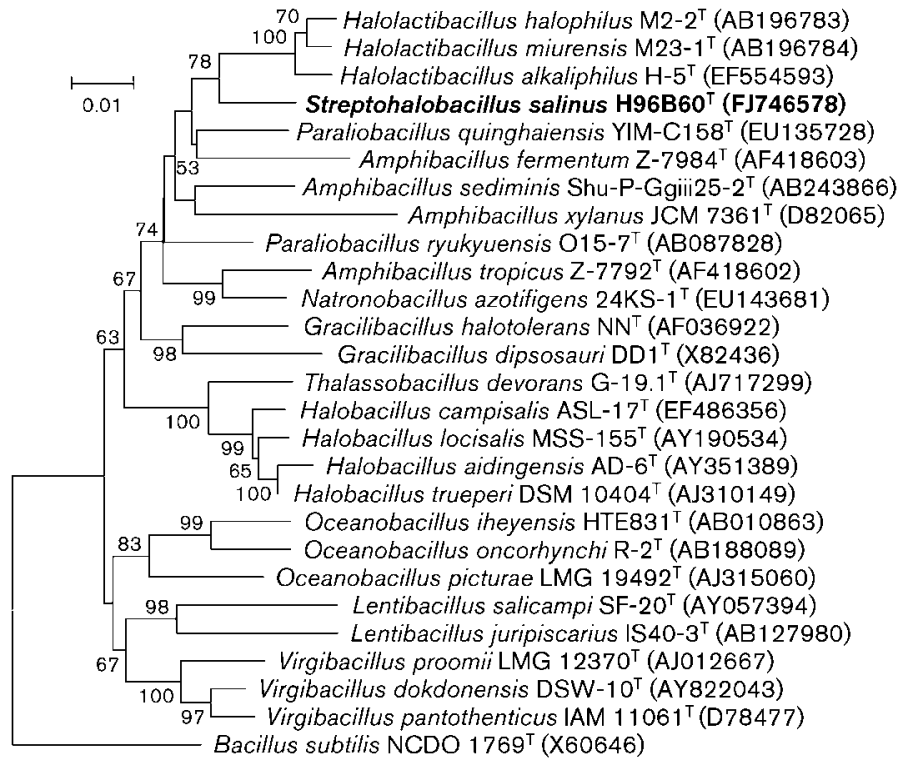

Fig. 1. Phylogenetic tree showing the relationships between strain $\mathrm{H} 96 \mathrm{~B}^{\mathrm{T}} \mathrm{O}^{\top}$ and some other related taxa based on 16S rRNA gene sequence analysis. Numbers at nodes represent percentage levels of bootstrap support, based on a neighbour-joining analysis of 1000 resampled datasets. Accession numbers of nucleotide sequences are given in parentheses. Bar, $1.0 \%$ sequence divergence. an oxidative metabolic pathway that is not mediated by the respiratory chain. The menaquinone component detected in cells of strain $\mathrm{H} 96 \mathrm{~B} 60^{\mathrm{T}}$ was MK-6, whereas no menaquinone components have been detected in cells of some species of the genus Halolactibacillus (Ishikawa et al., 2005). Cao et al. (2008) reported that Halolactibacillus alkaliphilus contained MK-9 $\left(\mathrm{H}_{2}\right)$ and MK-9 $\left(\mathrm{H}_{4}\right)$ as predominant isoprenoid quinone components. We did not detect any menaquinone components in cells of $H$. alkaliphilus NBRC $103919^{\mathrm{T}}$ in parallel experiments. Regardless, the menaquinone component of strain $\mathrm{H} 96 \mathrm{~B} 60^{\mathrm{T}}$ differed significantly from that of members of the genus Halolactibacillus. Moreover, H. halophilus NBRC $103919^{\mathrm{T}}$ produced lactate, formate, acetate and ethanol from glucose without gas production under anaerobic conditions; the molar ratio of formate, acetate and ethanol was approximately $2: 1: 1$. However, strain $\mathrm{H} 96 \mathrm{~B} 60^{\mathrm{T}}$ did not produce formate as a fermentative metabolite from glucose. Under anaerobic conditions, strain $\mathrm{H} 96 \mathrm{~B} 60^{\mathrm{T}}$ produced lactate at yields of $65 \%$ of the amount of glucose consumed. The other fermentative metabolic end products from glucose were acetate and ethanol at a molar ratio of approximately $1: 3$. No gas was produced. Carbon recovery from glucose consumed was about $94 \%$ (Supplementary Table S2). These data indicated that the new isolate may have a different pathway of glucose fermentation from members of the genus Halolactibacillus. In addition, some phenotypic features also differentiate strain $\mathrm{H} 96 \mathrm{~B} 60^{\mathrm{T}}$ from species of the genus Halolactibacillus (Table 1). Furthermore, the DNA G $+\mathrm{C}$ content of strain $\mathrm{H} 96 \mathrm{~B} 60^{\mathrm{T}}$ (36.2 mol\%) was lower than the range reported for Halolactibacillus species (38.3-40.7 mol\%).

In conclusion, the phenotypic, chemotaxonomic and phylogenetic data presented suggest that strain $\mathrm{H} 96 \mathrm{~B} 60^{\mathrm{T}}$ represents a novel species of a new genus, for which the name Streptohalobacillus salinus gen. nov., sp. nov. is proposed.

\section{Description of Streptohalobacillus gen. nov.}

Streptohalobacillus [Strep'to.ha.lo.ba.cil'lus. Gr. adj. streptos pliant, bent; Gr. n. hals salt; L. masc. n. bacillus stick, a small rod; N.L. masc. n. Streptohalobacillus a pliant or bent, salt (-loving) rod].

Cells are Gram-stain-positive, facultatively anaerobic, nonsporulating rods, occurring singly, in pairs or in short or long chains. Cells are motile by means of peritrichous flagella. Growth occurs in the absence of sugars. Acetate, ethanol and lactic acid are major metabolic end products from glucose under anaerobic fermentation conditions. Oxidase-positive but catalase-negative. Nitrate is reduced to nitrite. The cell-wall peptidoglycan type is $\mathrm{A} 1 \gamma$ with mesodiaminopimelic acid as the diagnostic diamino acid. The predominant cellular fatty acids are $\mathrm{C}_{16: 0}$, anteiso- $\mathrm{C}_{13: 0}$ and anteiso- $\mathrm{C}_{15: 0}$. The major isoprenoid quinone is MK-6. Phylogenetically, the genus is a member of the family Bacillaceae. The type species is Streptohalobacillus salinus.

\section{Description of Streptohalobacillus salinus sp. nov.}

Streptohalobacillus salinus (sa.li'nus. N.L. masc. adj. salinus salted, salty).

Exhibits the following properties in addition to those given in the genus description. Cells are $0.2-0.4 \times 2-8 \mu \mathrm{m}$, occurring as single short rods in liquid GM medium under aerobic conditions, but as long chains in exponential growth phase in liquid GM medium under anaerobic conditions. After cultivation on $\mathrm{GM}$ agar at $37{ }^{\circ} \mathrm{C}$ for 4 days, colonies are circular, white, opaque, slightly convex and $0.2-0.4 \mathrm{~mm}$ in diameter. Grows at $20-40{ }^{\circ} \mathrm{C}$ (optimum $37^{\circ} \mathrm{C}$ ), at $\mathrm{pH}$ 6.5-9.0 (optimum pH 7.5) and with $0-20 \%$ (w/v) $\mathrm{NaCl}$ [optimum $7 \%$ (w/v) $\mathrm{NaCl}$ ]. Positive in tests for methyl red reaction, amylase, 
Table 1. Differential phenotypic characteristics between strain $\mathrm{H} 6 \mathrm{~B} \mathrm{O}^{\top}$ and closely related members of the family $\mathrm{Bacillaceae}$

Taxa: 1, strain H96B60 ${ }^{\mathrm{T}}$; 2, Halolactibacillus; 3, Amphibacillus; 4, Natronobacillus; 5, Paraliobacillus; 6, Gracilibacillus. Data are from Ishikawa et al. (2002, 2005), Cao et al. (2008), Niimura et al. (1990), An et al. (2007), Sorokin et al. (2008), Wainø et al. (1999), Zhilina et al. (2001), Jeon et al. (2008), Carrasco et al. (2006), Chen et al. (2008), Ahmed et al. (2007) and this study. v, Variable; W, weakly positive; ND, no data available.

\begin{tabular}{|c|c|c|c|c|c|c|}
\hline Characteristic & 1 & 2 & 3 & 4 & 5 & 6 \\
\hline Spore formation & - & - & + & + & + & + \\
\hline Anaerobic fermentation & + & + & + & + & + & - \\
\hline $\begin{array}{l}\text { Glucose required under } \\
\text { aerobic conditions }\end{array}$ & - & + & + & ND & + & - \\
\hline $\mathrm{NaCl}$ range $(\%, \mathrm{w} / \mathrm{v})$ & $0-20$ & $0-25.5$ & $0-20.9$ & $11-23$ & $0-22$ & $0.5-20$ \\
\hline $\mathrm{pH}$ range & $6.5-9.0$ & $6-10$ & $7.0-11.5$ & $7.5-10.6$ & $5.5-9.5$ & $5-10$ \\
\hline Temperature range $\left({ }^{\circ} \mathrm{C}\right)$ & $20-40$ & $5-45$ & $17-56$ & ND & $10-47.5$ & $4-50$ \\
\hline Oxidase & + & - & ND & ND & ND & v \\
\hline Nitrate reduction & + & - & $\mathrm{ND}$ & - & - & $\mathrm{v}$ \\
\hline Starch hydrolysis & + & W & ND & + & + & $\mathrm{V}$ \\
\hline $\begin{array}{l}\text { Major end products from } \\
\text { glucose under anaerobic } \\
\text { conditions }^{*}\end{array}$ & A, E, L & F, A, E, L & $\mathrm{F}, \mathrm{A}, \mathrm{E}$ & $\mathrm{A}, \mathrm{F}, \mathrm{E}$ & F, A, E, L & None \\
\hline Major cellular fatty acids $\dagger$ & $\begin{array}{c}\mathrm{C}_{16: 0}, \text { ai- } \mathrm{C}_{13: 0} \\
\text { ai- } \mathrm{C}_{15: 0}\end{array}$ & ai- $C_{13: 0}, C_{16: 0}$ & $\begin{array}{c}\text { ai- } C_{15: 0}, C_{16: 0} \\
\text { i- } C_{16: 0}\end{array}$ & $\begin{array}{l}\text { ai- } \mathrm{C}_{15: 0}, \mathrm{i}-\mathrm{C}_{15: 0} \\
\text { ai- } \mathrm{C}_{13: 0}, \mathrm{C}_{16: 0}\end{array}$ & ND & $\begin{array}{c}\text { ai- } \mathrm{C}_{15: 0}, \mathrm{i}-\mathrm{C}_{15: 0}, \\
\text { ai- } \mathrm{C}_{17: 0}\end{array}$ \\
\hline Major isoprenoid quinone & MK-6 & None $\ddagger$ & None & $\mathrm{ND}$ & MK-7 & MK-7 \\
\hline $\begin{array}{l}\text { DNA G }+ \text { C content } \\
(\mathrm{mol} \%)\end{array}$ & 36.2 & $38.3-40.7$ & $36.0-42.3$ & $36.1-38.5$ & 35.6 & $38-39$ \\
\hline Isolation source(s) & Saline soil & $\begin{array}{c}\text { Decaying marine algae, } \\
\text { living sponge, } \\
\text { sediment }\end{array}$ & $\begin{array}{l}\text { Alkaline manure } \\
\text { with grass and rice } \\
\text { straw, sediment }\end{array}$ & $\begin{array}{l}\text { Soda soils and } \\
\text { lakes }\end{array}$ & $\begin{array}{c}\text { Decomposing } \\
\text { algae }\end{array}$ & Saline lake \\
\hline
\end{tabular}

${ }^{*}$ A, Acetate; E, ethanol; F, formate; L, lactate.

$\dagger$ ai, Anteiso-branched; i, iso-branched.

$\ddagger$ Cao et al. (2008) reported that $H$. alkaliphilus contained MK- $9\left(\mathrm{H}_{2}\right)$ and MK- $9\left(\mathrm{H}_{4}\right)$ as predominant isoprenoid quinone components. However, menaquinone components were not detected in cells of $H$. alkaliphilus $\mathrm{NBRC} 103919^{\mathrm{T}}$ in our experiments.

pullulanase and $\beta$-glucosidase, but negative in tests for $\mathrm{H}_{2} \mathrm{~S}$ production, indole production, Voges-Proskauer reaction, urease production, protease, lipase, DNase, phosphatase and gelatinase. Acid is produced from glycerol, D-xylose, Dglucose, D-fructose, D-mannose, D-mannitol, $\mathrm{N}$-acetylglucosamine, amygdalin, aesculin, salicin, cellobiose, maltose, sucrose, trehalose, melezitose, raffinose, starch, glycogen, xylitol, gentiobiose, turanose, D-arabitol and potassium 5-ketogluconate, but not from L-arabinose, D-galactose, Lsorbose, L-rhamnose, arbutin, melibiose, D-sorbitol, erythritol, D-ribose, D-arabinose, L-xylose, D-adonitol, methyl $\beta$-D-xylopyranoside, dulcitol, inositol, methyl $\alpha$-D-glucopyranoside, inulin, lactose, lyxose, D-tagatose, $\mathrm{D}$ - and $\mathrm{L}$ fucose, L-arabitol, potassium gluconate, 2-ketogluconate or methyl $\alpha$-D-mannopyranoside. Susceptible to ampicillin $(10 \mu \mathrm{g})$, penicillin $\mathrm{G}(10 \mathrm{U})$, cefazolin $(30 \mu \mathrm{g})$, gentamicin $(10 \mu \mathrm{g})$, streptomycin $(10 \mu \mathrm{g})$, tetracycline $(30 \mu \mathrm{g})$, chloramphenicol $(30 \mu \mathrm{g})$, clindamycin $(2 \mu \mathrm{g})$, erythromycin $(15 \mu \mathrm{g})$, norfloxacin $(10 \mu \mathrm{g})$, vancomycin $(30 \mu \mathrm{g})$, ciprofloxacin $(5 \mu \mathrm{g})$, kanamycin $(30 \mu \mathrm{g})$, neomycin $(30 \mu \mathrm{g})$, polymyxin B $(300 \mathrm{U})$, rifampicin $(5 \mu \mathrm{g})$, spectinomycin $(100 \mu \mathrm{g})$, josamycin $(15 \mu \mathrm{g})$, medicamycin $(15 \mu \mathrm{g})$, bacitracin $(0.04 \mathrm{U})$ and novobiocin $(5 \mu \mathrm{g})$. The genomic DNA
$\mathrm{G}+\mathrm{C}$ content of the type strain is $36.2 \mathrm{~mol} \%\left(T_{\mathrm{m}}\right.$ method).

The type strain, H96B60 ${ }^{\mathrm{T}}$ (=DSM $22440^{\mathrm{T}}=\mathrm{CGMCC}$ $1.7733^{\mathrm{T}}$ ), was isolated from a saline soil sample of the Qaidam basin, China.

\section{Acknowledgements}

This work was supported by grants from the Ministry of Science and Technology of China (973 Programs: 2007CB707801; 863 Programs: 2006AA020201 and 2007AA021306) and the Chinese Academy of Sciences (Knowledge Innovation program: KSCX2-YW-G-011).

\section{References}

Ahmed, I., Yokota, A. \& Fujiwara, T. (2007). Gracilibacillus boraciitolerans sp. nov., a highly boron-tolerant and moderately halotolerant bacterium isolated from soil. Int J Syst Evol Microbiol 57, 796-802.

An, S. Y., Ishikawa, S., Kasai, H., Goto, K. \& Yokota, A. (2007). Amphibacillus sediminis sp. nov., an endospore-forming bacterium isolated from lake sediment in Japan. Int J Syst Evol Microbiol 57, 2489-2492. 
Ash, C., Farrow, J. A. E., Wallbanks, S. \& Collins, M. D. (1991). Phylogenetic heterogeneity of the genus Bacillus as revealed by comparative analysis of small-subunit-ribosomal RNA sequences. Lett Appl Microbiol 13, 202-206.

Cao, S. J., Qu, J. H., Yang, J. S., Sun, Q. \& Yuan, H. L. (2008). Halolactibacillus alkaliphilus sp. nov., a moderately alkaliphilic and halophilic bacterium isolated from a soda lake in Inner Mongolia, China, and emended description of the genus Halolactibacillus. Int J Syst Evol Microbiol 58, 2169-2173.

Carrasco, I. J., Márquez, M. C., Yanfen, X., Ma, Y., Cowan, D. A., Jones, B. E., Grant, W. D. \& Ventosa, A. (2006). Gracilibacillus orientalis sp. nov., a novel moderately halophilic bacterium isolated from a salt lake in Inner Mongolia, China. Int J Syst Evol Microbiol 56, 599-604.

Carrasco, I. J., Márquez, M. C., Xue, Y., Ma, Y., Cowan, D. A., Jones, B. E., Grant, W. D. \& Ventosa, A. (2008). Sediminibacillus halophilus gen. nov., sp. nov., a moderately halophilic, Gram-positive bacterium from a hypersaline lake. Int J Syst Evol Microbiol 58, 1961-1967.

Chen, Y. G., Cui, X. L., Zhang, Y. Q., Li, W. J., Wang, Y. X., Xu, L. H., Peng, Q., Wen, M. L. \& Jiang, C. L. (2008). Gracilibacillus halophilus sp. nov., a moderately halophilic bacterium isolated from saline soil. Int J Syst Evol Microbiol 58, 2403-2408.

Collins, M. D., Pirouz, T., Goodfellow, M. \& Minnikin, D. E. (1977). Distribution of menaquinones in actinomycetes and corynebacteria. J Gen Microbiol 100, 221-230.

Duckworth, A. W., Grant, W. D., Jones, B. E. \& Steenbergen, R. V. (1996). Phylogenetic diversity of soda lake alkaliphiles. FEMS Microbiol Ecol 19, 181-191.

Felsenstein, J. (1985). Confidence limits on phylogenies: an approach using the bootstrap. Evolution 39, 783-791.

García, M. T., Gallego, V., Ventosa, A. \& Mellado, E. (2005). Thalassobacillus devorans gen. nov., sp. nov., a moderately halophilic, phenol-degrading, Gram-positive bacterium. Int J Syst Evol Microbiol 55, 1789-1795.

Groth, I., Schumann, P., Weiss, N., Martin, K. \& Rainey, F. A. (1996). Agrococcus jenensis gen. nov., sp. nov., a new genus of actinomycetes with diaminobutyric acid in the cell wall. Int J Syst Bacteriol 46, 234239.

Heyndrickx, M., Lebbe, L., Kersters, K., De Vos, P., Forsyth, G. \& Logan, N. A. (1998). Virgibacillus: a new genus to accommodate Bacillus pantothenticus (Proom and Knight 1950). Emended description of Virgibacillus pantothenticus. Int J Syst Bacteriol 48, 99-106.

Ishikawa, M., Ishizaki, S., Yamamoto, Y. \& Yamasato, K. (2002). Paraliobacillus ryukyuensis gen. nov., sp. nov., a new Gram-positive, slightly halophilic, extremely halotolerant, facultative anaerobe isolated from a decomposing marine alga. J Gen Appl Microbiol 48, 269-279.

Ishikawa, M., Nakajima, K., Yanagi, M., Yamamoto, Y. \& Yamasato, K. (2003). Marinilactibacillus psychrotolerans gen. nov., sp. nov., a halophilic and alkaliphilic marine lactic acid bacterium isolated from marine organisms in temperate and subtropical areas of Japan. Int J Syst Evol Microbiol 53, 711-720.

Ishikawa, M., Nakajima, K., Itamiya, Y., Furukawa, S., Yamamoto, Y. \& Yamasato, K. (2005). Halolactibacillus halophilus gen. nov., sp. nov. and Halolactibacillus miurensis sp. nov., halophilic and alkaliphilic marine lactic acid bacteria constituting a phylogenetic lineage in Bacillus rRNA group 1. Int J Syst Evol Microbiol 55, 2427-2439.

Jeffries, C. D., Holtman, D. F. \& Guse, D. G. (1957). Rapid method for determining the activity of microorganisms on nucleic acids. J Bacteriol 73, 590-591.

Jeon, C. O., Lim, J. M., Jang, H. H., Park, D. J., Xu, L. H., Jiang, C. L. \& Kim, C. J. (2008). Gracilibacillus lacisalsi sp. nov., a halophilic
Gram-positive bacterium from a salt lake in China. Int J Syst Evol Microbiol 58, 2282-2286.

Kämpfer, P. \& Kroppenstedt, R. M. (1996). Numerical analysis of fatty acid patterns of coryneform bacteria and related taxa. Can J Microbiol 42, 989-1005.

Kumar, S., Tamura, K. \& Nei, M. (2004). MEGA3: integrated software for molecular evolutionary genetics analysis and sequence alignment. Brief Bioinform 5, 150-163.

Kushner, D. J. (1985). The Halobacteriaceae. In The Bacteria, a Treatise on Structure and Function, vol. VIII, pp. 171-206. Edited by I. C. Gunsalus, C. R. Woese \& R. S. Wolfe. San Diego: Academic Press.

Kwon, K. S., Lee, J., Kang, H. G. \& Hah, Y. C. (1994). Detection of $\beta$ glucosidase activity in polyacrylamide gels with esculin as substrate. Appl Environ Microbiol 60, 4584-4586.

Lu, J., Nogi, Y. \& Takami, H. (2001). Oceanobacillus iheyensis gen. nov., sp. nov., a deep-sea extremely halotolerant and alkaliphilic species isolated from a depth of $1050 \mathrm{~m}$ on the Iheya Ridge. FEMS Microbiol Lett 205, 291-297.

Marmur, J. (1961). A procedure for the isolation of deoxyribonucleic acid from micro-organisms. J Mol Biol 3, 208-218.

Marmur, J. \& Doty, P. (1962). Determination of the base composition of deoxyribonucleic acid from its thermal denaturation temperature. J Mol Biol 5, 109-118.

Nielsen, P., Rainey, F. A., Outtrup, H., Priest, F. G. \& Fritze, D. (1994). Comparative $16 \mathrm{~S}$ rDNA sequence analysis of some alkaliphilic bacilli and the establishment of a sixth rRNA group within the genus Bacillus. FEMS Microbiol Lett 117, 61-65.

Niimura, Y., Koh, E., Yanagida, F., Suzuki, K., Komagata, K. \& Kozaki, M. (1990). Amphibacillus xylanus gen. nov., sp. nov., a facultatively anaerobic sporeforming xylan-digesting bacterium which lacks cytochrome, quinone, and catalase. Int J Syst Bacteriol 40, 297301.

Priest, F. G. (1981). DNA homology in the genus Bacillus. In The Aerobic Endospore-forming Bacteria, pp. 33-57. Edited by R. C. Berkeley \& M. Goodfellow. London: Academic Press.

Quesada, E., Ventosa, A., Ruiz-Berraquero, F. \& Ramos-Cormenzana, A. (1984). Deleya halophila, a new species of moderately halophilic bacteria. Int J Syst Bacteriol 34, 287-292.

Ren, P. G. \& Zhou, P. J. (2005). Tenuibacillus multivorans gen. nov., sp. nov., a moderately halophilic bacterium isolated from saline soil in Xin-Jiang, China. Int J Syst Evol Microbiol 55, 95-99.

Ryan, S. M., Fitzgerald, G. F. \& van Sinderen, D. (2006). Screening for and identification of starch-, amylopectin-, and pullulan-degrading activities in bifidobacterial strains. Appl Environ Microbiol 72, 52895296.

Sánchez-Porro, C., Martín, S., Mellado, E. \& Ventosa, A. (2003). Diversity of moderately halophilic bacteria producing extracellular hydrolytic enzymes. J Appl Microbiol 94, 295-300.

Saqib, A. \& Whitney, P. J. (2006). Esculin gel diffusion assay (EGDA): a simple and sensitive method for screening $\beta$-glucosidases. Enzyme Microb Technol 39, 182-184.

Sasser, M. (1990). Identification of bacteria by gas chromatography of cellular fatty acids, Technical Note 101. Newark, DE: MIDI, Inc.

Schleifer, K. H. \& Kandler, O. (1972). Peptidoglycan types of bacterial cell walls and their taxonomic implications. Bacteriol Rev 36, 407-477.

Schlesner, H., Lawson, P. A., Collins, M. D., Weiss, N., Wehmeyer, U., Völker, H. \& Thomm, M. (2001). Filobacillus milensis gen. nov., sp. nov., a new halophilic spore-forming bacterium with Orn-D-Glu-type peptidoglycan. Int J Syst Evol Microbiol 51, 425-431.

Sehgal, S. N. \& Gibbons, N. E. (1960). Effect of some metal ions on the growth of Halobacterium cutirubrum. Can J Microbiol 6, 165-169. 
Sorokin, I. D., Zadorina, E. V., Kravchenko, I. K., Boulygina, E. S., Tourova, T. P. \& Sorokin, D. Y. (2008). Natronobacillus azotifigens gen. nov., sp. nov., an anaerobic diazotrophic haloalkaliphile from sodarich habitats. Extremophiles 12, 819-827.

Spring, S., Ludwig, W., Marquez, M. C., Ventosa, A. \& Schleifer, K. H. (1996). Halobacillus gen. nov., with descriptions of Halobacillus litoralis sp. nov., and Halobacillus trueperi sp. nov., and transfer of Sporosarcina halophila to Halobacillus halophilus comb. nov. Int J Syst Bacteriol 46, 492-496.

Stackebrandt, E. \& Liesack, W. (1993). Nucleic acids and classification. In Handbook of New Bacterial Systematics, pp. 152-189. Edited by M. Goodfellow \& A. G. O’Donnell. London: Academic Press.

Thompson, J. D., Gibson, T. J., Plewniak, F., Jeanmougin, F. \& Higgins, D. G. (1997). The CLUSTAL_X windows interface: flexible strategies for multiple sequence alignment aided by quality analysis tools. Nucleic Acids Res 25, 4876-4882.

Ventosa, A., Quesada, E., Rodriguez-Valera, F., Ruiz-Berraquero, F. \& Ramos-Cormenzana, A. (1982). Numerical taxonomy of moderately halophilic Gram-negative rods. J Gen Microbiol 128, 19591968.
Ventosa, A., Nieto, J. J. \& Oren, A. (1998). Biology of moderately halophilic aerobic bacteria. Microbiol Mol Biol Rev 62, 504-544.

Wainø, M., Tindall, B. J., Schumann, P. \& Ingvorsen, K. (1999). Gracilibacillus gen. nov., with description of Gracilibacillus halotolerans gen. nov., sp. nov.; transfer of Bacillus dipsosauri to Gracilibacillus dipsosauri comb. nov., and Bacillus salexigens to the genus Salibacillus gen. nov., as Salibacillus salexigens comb. nov. Int J Syst Bacteriol 49, 821-831.

Wang, X. W., Xue, Y. F. \& Ma, Y. H. (2009). Sediminibacillus albus sp. nov., a moderately halophilic, Gram-positive bacterium isolated from a hypersaline lake, and emended description of the genus Sediminibacillus Carrasco et al. 2008. Int J Syst Evol Microbiol 59, 1640-1644.

Yoon, J. H., Kang, K. H. \& Park, Y. H. (2002). Lentibacillus salicampi gen. nov., sp. nov., a moderately halophilic bacterium isolated from a salt field in Korea. Int J Syst Evol Microbiol 52, 2043-2048.

Zhilina, T. N., Garnova, E. S., Tourova, T. P., Kostrikina, N. A. \& Zavarzin, G. A. (2001). Amphibacillus fermentum sp. nov. and Amphibacillus tropicus sp. nov., new alkaliphilic, facultatively anaerobic, saccharolytic bacilli from Lake Magadi. Microbiology (English translation of Mikrobiologiia) 70, 711-722. 